\title{
Marginalized Minority Groups In Europe In The Context Of The Clash Of Civilisations: The Case Of Muslims
}

\author{
Muserref Yardim, Assistant Prof. \\ Erhan Tecim, Assistant Prof. \\ Necmettin Erbakan University
}

doi: 10.19044/esj.2016.v12n11p265 URL:http://dx.doi.org/10.19044/esj.2016.v12n11p265

\begin{abstract}
One of the most important issues faced by the European civilization is immigrants. These immigrants are not considered to be European, can be marginalized due to national-ethnic-religious reasons, and defined in the invisible European 'other'. This attitude is not rational at all for the European civilization and it is on the agenda of many European countries on the verge of the 21st Century. With political decisions taken and practices put into effect, the existing distinction is being clarified and efforts are exerted to make the increasing contrast extant. It has become quite a common situation for many European countries that individuals, especially politicians, coming to the agenda with clearly Eurocentric rhetorics, increase their popularity and serve to exclusionary rhetorics along with such popularity. The social category which is the basic object of such an action again becomes the emigrating citizens of Muslim countries which were included in the colonization movements a few centuries before as well as the people of Muslim countries who were invited to European countries by the latter due to the labour needs. In addition to passing of at least 70 years since they were recruited as labour force, the third and fourth generation Muslims have preferred to remain as citizens in several European countries. It should be emphasized that social and political issues started at this point. It is a pleasing and rational development for harmony and coexistence that those people who were once regarded as religious minorities or Muslim minorities are beginning to have a voice. Yet, it needs emphasizing that this situation is unacceptable in most cases, national policies complicate harmonization rather than facilitating, and a considerable part of the European countries subject them to otherisation due to their different ethnic and religious identity, and most importantly they are not accepted in European countries.
\end{abstract}


Keywords: Multiculturalism, İslamophobia, the Clash of Civilizations, Cohesion, Exclusion

\section{Introduction}

It is attempted to indoctrinate the 'clash of civilizations' thesis, which is conceptualized in a controversial manner, and a conception of civilization in the 'East-West' dichotomy. In this way, new discussion topics are exacerbated on which sociologists can have a word in their respective discipline. The concepts such as discrimination, sexism, racism, assimilation, integration, multiculturalism, xenophobia, İslamophobia, and so on have been debated for long years. However, the debates have gained other dimensions since the beginning of the 21st century, particularly after the September 11 attacks. As a consequence, orientalist views which bring to life the distinction between 'we' and 'they' are brought to the agenda again. Europe identifies “others" with Muslims, religious minorities and migrants. In this regard, the minority issue in Europe is both very complicated and of crucial importance.

In lexical context, the term "minority" 'is defined as those distinct in any respect and outnumbered by others in a community; yet, it is a concept of sociological and legal expansions' (Terzioğlu and Özarslan, 2005:113).

Definition of the concept of minority seems quite difficult and raises two questions: First, how should distinction be made between so-called minority group and linguistic, religious and ethnic minority groups? Second, what are the criteria which distinguish minority groups from indigenous people? (Rigaux, 1997: 155).

Although there is not a universal definition for the term minority and it is rather hard to define it, the definition provided by Capotorti, the rapporteur of the Sub-Commission on Prevention of Discrimination and Protection of Minorities, is among the most widely accepted ones. According to him, minority refers to 'the group which is not in a dominant position, in a smaller number than the rest of the population of a state, whose members that are nationals of the state differ from the rest of the population from ethnic, religious and linguistic aspects, and which has a sense of solidarity for protection of its own culture, traditions and language, not overtly albeit' (Oran, 2001:67). He also refers to subjective conditions for describing any group as a minority group. Thus, Capotorti defined this concepts as '...the existence of a minority consciousness. Just as classes cannot exist without class consciousness, individuals or groups cannot form a minority group unless they become aware that they are different and take such difference as an indispensable condition of their identity. This is the subjective condition of the concept of minority and is of great importance. For example, a person 
or group which wants to be assimilated into the majority on a voluntary basis (to dissolve in majority) is not considered minority' (Oran, 2004:18).

Following Capotorti's definition of minority in 1979, Jules Deschênes carried out a study on minorities in 1985 upon the SubCommission's request. In his study, Deschênes discussed the concept of minority as '... a social group with minority status in quantitative terms in the population of a country, not acting as administrator, historically occupying a certain part of the said state's territory, with members who are accepted as citizens of the state have different ethnic, religious, linguistic or cultural characteristics from the rest of the population and exhibiting an overt or covered solidarity for protection of their own culture, traditions, religion and language'(Preece, 2001:39).

However, the formal definition of minorities by the UN is based on the definition adopted in 1949 by Human Rights Commission, the SubCommission on Prevention of Discrimination and Protection of Minorities. According to the Commission, 'groups which are not in a dominant status, have constant ethnic, linguistic or religious traditions or other important features within a community, differing clearly from other sections of the society with these characteristics and which wish to preserve these features' are called minorities (Arsava, 1993:42-43).

In relation with protection of minorities, it is seen that the gap which was initially existent in primary law of the European Union is tried to be closed with case law and the Lisbon Agreement. Besides the European Human Rights Commission(ECHR), the European Council National Minorities Framework Convention, common constitutional traditions of member states and the EU Fundamental Rights Charter play a role in shaping of the EU legislation on protection of minorities. To the extent accepted as a constitutional principle in the EU acquis, protection of minorities lays the basis for dispositions established in the EU institutional structure and enforcement of the EU acquis by the member states, and is regarded as a political criterion that must be met by EU-candidate countries (Arsava, 2010: $1)$.

\section{Religious Minorities and Muslims}

For understanding of İslamophobia, inclusion of Muslims as the largest religious minority especially in Western Europe and the level of the relationship established between Muslims and non-Muslims is seen to be the main determinant. Gradually increasing number of Muslims in Europe further increases the importance of this relationship (Çötok and Taşdelen, 2013:2).

We can find the reasons for Christianity's being one of the most important elements in definition of 'the European identity' by looking at a 
line coming from the history. In Europe, the fall of the Iron Curtain, the European Union's enlargement, revival of nationalist and racist movements have led to debates on the identity of Europe in the West. On the other hand, the fact that ethnic and religious are still determinants has maintained its rank on the agenda, despite the promotion of the understanding of cultural pluralism. It is known that imitations and sensitivity concerning religiousnational-ethnic identity in Europe, whether based on secular grounds or Christianity-related grounds, to cause legal and social discrimination against religious minorities. When viewed from this perspective, it is seen that Europe has not yet overcome its problems related to religious and ethnic minorities (Şenay, 2002: 128).

In the UN studies, the 'religious minorities' concept is understood in its most comprehensive form and has been used in a way to include the concept of freedom (of thought, conscience and religion) in parallel with Article 18 of the International Covenant on Civil and Political Rights. A religious affiliation is a personal decision and a subjective thing. Nevertheless, if a religious group has certain objective characteristics (traditions, shared history, organizing and group members in relation with each other), it is recognized as a minority. In this respect, it is not necessarily applicable that every religious community which is in the minority status compared to one or more larger religious communities constitutes minority within the meaning of Article 27 (Altınay, 2004 :337).

In the context of integration of Muslims into the communities of the countries in which they live, the probable role played by religion is mentioned often. The subject of integration in the European Union continues to be up-to-date. Although nearly half a century has passed since Muslims started living in European countries and Muslims have made significant contributions to economic and cultural development of those countries since then, it emerges as a serious problem that legitimacy of the presence of Muslims is being questioned. 'Minority' and 'majority' categories are sociological concepts of integration and assimilation phenomena. In sociological terms, minority means the 'small' number of people (minorities), while majority (majorities) means the group of people that makes up the majority of a community in ethnic background, religious and cultural aspects. Majority having influence and power is usually at the center of the carrier culture of the society, whereas minority with limited influence is located outside or at the edge of the carrier power (Kuyucuoğlu, 2013:385386).

In its study Muslims in the European Union: Discrimination and Islamophobia, the EUMC prepared a report on Muslims in the European Union member states. In the report, emphasis is made on the need to 'address 
enmity against Muslims in the wider context, in the context of xenophobia and racism towards migrants and minorities' (EUMC, 2006:40).

However, now states have begun to address ethno-cultural and religious differences of minorities or immigrants in the scope of the state's security rather than normal democratic negotiations since immigrant cultures have begun to be perceived as a threat to national, social and cultural assets of the majority. This case implies that the opportunities of the minorities and migrants to negotiate for democratic participation or for their rights could be restricted on the grounds of 'state security'. Though the form of discrimination against migrants varies depending on the cultures of these groups, it has also started to come up as 'Islamophobia' especially after 11 September 2001. Similarly, it is stated that racism in German society and particularly discrimination against Muslim Turks has increased in recent years. In addition, it is said that the view that 'Germany jeopardizes its future due to the wrong immigrants from Muslim countries' advocated in the Social Democratic Party member Thilo Sarrazin's book “ Germany Does Away With Itself” is being used by politicians to get votes and it has spread among people (Özgür, 2012: 74).

\section{Europe's Minorities: 'Immigrant' Muslims}

It was raised by the report by The Council of Europe Eminent Persons Group that European society comprises diversity and differences with its minority and majority, and such diversity is destiny for Europe. The report also refers to the need for diversity in Europe as following: 'First, most of those who came to Europe over the past decade and their children are permanent in Europe. Majority of them continue their commitment to the culture of their home countries. Is this something wrong? As long as they obey the laws, those who have begun to live in another country should not be expected to give up their faith, culture or identity. As a matter of fact, today the diversity can contribute to the creativity needed in Europe more than ever. But this, in turn, means that it is necessary to look beyond Europe to build a life together in Europe. The happenings in places left behind by new Europeans, especially in countries neighboring Europe, will affect all of us for better or worse. We cannot determine the fate of our neighbors, but we have to be as ready as possible to help them and to learn from them. Second, the increasingly aging population of Europe means that there is more need for immigrants. According to predictions of the European Commission, even though total population continues to increase, overall labour force in the European Union will be nearly 100 million people less over the next 50 years if immigrants do not exist. This in turn means an invitation to Europe's decline (Council of Europe, 2011: 7-8). 
Muslim groups' being perceived as a problem of 'religious minority' (Baumann, 2006: 30) is realized in the context of migration and integration. Associating of immigration and integration led to accusation of cultural differences of minorities for social problems. Until 1990s, the issue of 'religious differences' and the role of religion with all its aspects did not draw attention of the society and was less concern to public policy. The situation changed in a short time. Religion can be said to be becoming an important issue for public policy regarding integration of the Muslim communities depending on parallel developments in Europe, functioning of the religion, and interaction with other non-Muslim groups in social life (Öztürk, 2014). The source of Europe's attitude against Muslims includes such dimensions as 'foreigners', 'migrant' and 'minority' (Aydın and Yardım, 2008: 11).

In brief, defining the Muslims living in Europe as 'minority' and 'migrant' in related talks shows that the concept of minority is directly related to the concept of migration/immigrant. Describing Muslims as both 'immigrants' and 'minority' brings stereotypes and discrimination against Muslims to agenda and places emphasis on the feeling of 'hostility'. Muslims, who are also a part of the European society, are being exposed to discrimination as the 'other' by being marked as 'minority' and 'immigrant'.

In addition, there is an increasing tendency to address ethno-cultural and religious differences of minorities or immigrants in the scope of 'state security' or 'national security' instead of normal democratic parliamentary debates because the culture of the immigrants has begun to be perceived as a threat to national, social and cultural assets of the majority. This implies that the opportunities of the minorities and migrants to negotiate for democratic participation or for their rights could be restricted on the grounds of 'state security' (Özgür, 2012: 78).

The best example of what the concept of migrant means in Europe can be the European Council's work titled Migrants and their descendantsGuide to policies for the well-being of all in pluralist societies. This study attempts to determine perceptions formed about immigrants in European societies by means of different methods (Council of Europe, 2011: 12-14).

1. 'Immigrants are causing an increase in crime'. It is seen that expressions such as following often repeated by the media, officials and some 'security experts' is accepted unquestioningly by a large segment of society: 'immigrants, especially illegal immigrants, are criminals'; 'immigrants obey laws less than local citizens do'; 'immigrants are responsible for most of the crimes'; 'they are coming in to our country to commit crime' and 'our cities and streets are less safe because of immigrants'.

1. 'Immigrants carry diseases into our country' or 'some diseases which had been eradicated in Europe years ago relapsed because of immigrants'. 
According to defenders of these claims, health status of irregular or undocumented migrants and their children is poorer than the rest of the country's population and infectious diseases in the immigrant communities are more prevalent than among the locals.

2. The understanding 'Migrant workers are taking away our business' is seen to be so common in European societies, especially among workers in sectors running a great number of immigrants. This view also applies to in a narrow sense, but also to those that are still not seen 'a part of the nation' due to the appearance and culture or family ties of immigrants' children, namely those called second generation.

3. 'Immigrants are causing a decrease of our fee': Although most people accept that there is no evidence that immigrants and local citizens are in direct competition for job, they hold the idea that wages decrease due to the presence of the immigrants.

4. 'Immigrants are abusing the possibilities of the welfare state': Immigrants and their families are accused of abusing the services offered by the state in three ways with the idea above. First, it is alleged that they use public services and assistance extremely a lot and unfairly, to which they are able to access in a more freely and less controlled manner than other citizens. Secondly, the opinion that they benefit from the assistance and services for which they do not have legal rights to access, so they clearly fraud against the locals outweighs. Lastly, they are claimed to earn from the economy much more than their contribution to it during the period through which they stay with the intention of enjoying the welfare in Europe, which is assumed to be temporary.

5. The idea 'Migrants are acting as if it is their own country where they are' is particularly common among older people. The idea has become widespread that newcomers do not respect them, so their lifestyle is disrupted, and 'immigrant culture and lifestyle receives more respect than ours'.

6. 'Immigrants form parallel societies': Immigrants are often identified as social and political groups that are foreign to members of the society in which they are. They attract attention when they behave as closed and selfcontained communities; on the other hand, open communities and those that make efforts to establish friendly relations with members of other groups do not attract much attention. 'They want to be on their own', 'they have no intention to be integrated into society', 'they do not speak our language', and 'all they want is to obtain rights without undertaking responsibilities' are among the most typical arguments.

7. 'Immigrant children are lowering standards in our schools': The accusations such as Immigrant kids 'fail in school because their parents do not have the skills and education to train them', 'they cannot speak the 
language of the country'; 'they are enrolled in school in the middle of the school year'; and 'in reality they do not know which culture they belong to' draw attention.

8. 'Immigrant women live as a minority': Non-European immigrants are generally referred to as 'undeveloped' in terms of civilization and particularly gender equality. This bias is especially directed against Muslims.

\section{Conflict of Civilizations and Ancient Hatred of Islam in the Context of 'We' and 'They'}

It does not seem to reflect the reality to argue that European countries' view of Muslims is abstracted from colonial and orientalist ideas. The debates starting upon Turkey's application for the EU accession can be the most striking example. As Millas states, 'East-West meeting' includes aspects related to quest for cultural and historical identity and sometimes acquires a political dimension; 'sometimes some issues called 'political' are basically nothing more than the problem of 'culture' and identity'. Due to this exact reason, whether speakers are European or Turkish, the issue is not directly related to simply fulfillment of the Copenhagen criteria or introducing reforms. Precisely for this reason, many of the representations made for Turkey and vast majority of their own depictions of Europe highlight the cultural policy dimension, and orientalist framework of the definitions is well marked (Kajanlığlu and Taş, 2009: 62).

The Orientalist discourse which places negative emphasis on superiority of the Western civilization and difference from the West is being carried through on cultural and ideological tools. The media, discourses of political leaders and ideologists, and cultural instruments such as literature and cinema impose the superiority of the Western politics and lifestyle on the people of the Middle East and the whole world. Thus, the emphasis placed on under development of the Middle East and developed status of the West is accepted, and makes legitimate the interventions made to bring in the acceptable Western administrative formats (Deniz, 2012: 170).

Departing from Edward Said's ideas, it is seen that Europe is simply not a geographical or regional phenomenon, but it is inextricably intertwined with cultural signification processes. In this respect, descriptions such as geographical differences, namely the 'lands of civilization' or 'lands of the primitive' emerge as tools to set limits. Such markings and boundaries simply do not take place in our minds: 'in parallel, 'they' become 'they' and both their lands and minds are marked as different 'from ours'. This 'imaginary geography acts in the establishment of a sense of identity through marking the distance and difference between what is close and what is remote (Said, 1978: 54-55). 
The thought of İslamophobia, which had supporters in philosophical and theological context, has maintained its popularity during the middle Ages. For example, it seems necessary to consider Luther's discourses and theological-philosophical tradition for understanding the religious, political and sociocultural dynamics of the contemporary Western civilization. Luther has been one of the pioneers of the idea which justifies politics with theological data by uniting theology and politics. Luther, using the term 'Turk' or 'Turks' to refer to Muslims from time to time, identified the concepts of 'Muslim' and 'Turk'; together with the papacy, and he regarded Turks as a common enemy (H1dır, 2007: 145). Therefore, origins of xenophobia and İslamophobia can be traced back to Luther.

From this point of view, the root of Western prejudice against Islam and Muslims can be searched in the history of the spread of Islam and establishment of a new civilization by Islam. The stance against Islam, which became even deeper as a consequence of the Crusades, reached its peak with moving of the Muslims to the center of Europe through Spain, Istanbul and Balkans until the $19^{\text {th }}$ century.

Huntington (2007: 84) arguing that the primary battleground of the new era will not be ideological or economic and tried to explain mankind's source of struggle with cultural foundations. A lot of publications have been published in the literature in order to understand what it means. This discussion will not be entered in all sizes, but a framework is drawn for philosophical-sociological foundations.

Beyond all these debates, there is a reality that the Europeans' past (especially after the immigrant wave of 1950s) and current attitude is not directed towards living with foreigners or development. In fact, in majority of the European countries, multiculturalism is now seen as a practice to be avoided. From the macro perspective, it is possible to see that immigrants are regarded to be a growing burden and a situation threatening the welfare state and politics. Entzinger (2006: 182) thinks that it is politically wrong to mention this at grassroots level even if there is no racism.

The September 11 attacks put an end to multiculturalism. Now the state's security demands have been about forcing for cultural homogeneity and assimilation, avoiding a pluralistic society and fear of difference (Hussain and Miller, 1996: 51). Muslims are seen as one of the greatest dangers for Europe besides being a definite other. If one looks carefully, it can be seen that Muslims are perceived as enemies in three different dimensions:

1. External enemies: At first, Muslims were perceived as a foreign enemy trying to invade the sacred Christian and European world. Hundred years of the Andalusian rule in southern Europe, repeated siege of Vienna by the Ottoman Empire, and existence of Iran as a combative country today. 
Although Europe is trying to abandon this hostile attitude, some conflicts break out at grassroots level. However, nothing is more dangerous than what happened between the US and the Arab Islamic world.

1. Internal enemy: Muslim immigrants have lived in lower class in cities every sense since they arrived in Europe as cheap and easy labor force. Naturally, education status of these Muslim immigrants is lower than a common French or German national. Therefore, they have tried to resolve their dissatisfaction by resorting to crime. In addition, the small ethnic areas they created within and outside the city have been feared potential criminal slots and they have often been arrested for security reasons without warning. 2. International terrorists: Especially after September 11, Muslims have found themselves in a state suitable to be called terrorists. People do not just see them as a source of crime, but also as the source of the terrorist attacks that could kill many people in a short period of time (Mochizuki, 2005: 7-9).

Oliver Roy (2003) in his article titled Euro-Islam, has long warned Europeans against radicalization of Muslims. He stresses that European Islam, after which he named his article, is an inherent radical threat to and starts his word by saying that a new sociological area is born to study.

As in Turkey, in Europe, the political tendency emerging as nationalism does not use a political language based on racial or cultural superiority. In the strategy of this tendency, the reaction to the groups defined as the "other" and the belief that they will exploit and occupy the country and hate crimes and discrimination against religious or cultural groups representing these structures are of importance. So, the fear of Islam called Islamophobia recently developed against the Muslim minorities in Europe is emerging as a result of marginalization perception of the European nationalism (Kalın, 2006: 1).

This attitude finds its basis not only in the political sphere but in the religious field. In a speech, Pope Benedict XVI stated that Hz. Muhammad had brought inhumane and satanic messages and he could not give something new except for spreading Islam by the sword (Kılıç, 2006: 27). The Pope continued his speech saying that the relationship between mind and God is weak in Islam. As then Prime Minister Tayyip Erdogan reacted to this event, the Italian Christian Democrats immediately presented a report for suspension of Turkey's EU accession process (Kılıç, 2006: 27; Yeni Şafak, 17 September 2006).

It would be an incomplete assessment to search foundations for the increasing Islamic opposition in cultural and religious reasons only. Discrimination is no longer practiced in order to gain status and prestige in Europe. Economic reasons now seem to be ahead of cultural reasons. Thus, it should not be overlooked that the source of the growing İslamophobia is not only cultural and religious but also economic. 
K1lıç (2006: 32, 36-37) states that Islamic opposition in Europe has to do with both measures taken against immigrants and concern arising from Turkey's EU accession process, and highlights that there are four main reasons for rise of İslamophobia:

1. After September 11, addressing of Islam together with the concepts of 'terrorism' and 'violence' by politicians as well as intellectuals has been effective in creation of İslamophobia. For example, according to interviews conducted in Germany, $80 \%$ of the German people associate the term Islam with 'terrorism' and 'oppression of women'.

1. In relation to internal politics of countries, using of Muslim immigrants as a significant material in domestic politics by extreme rightists, nationalists in other words, has caused both politicization of the issue and has fueled İslamophobia in the society.

2. Disdaining religion emerging at a global level and the fashion of extreme secularization has led to an increase of exclusionary policies against religion and religious people.

3. Since active participation of member states' peoples came to the agenda as a result of gradual formation of the European identity, it has become inevitable to face negativity such as 'xenophobia', 'İslamophobia', 'gender debate', 'discrimination', and 'racism' arising from historical and cultural prejudices.

Also the fact that religious needs such as headscarf, immolation, and asking for halal meat occupies much space on the agenda has also carried the face of Islam and Muslims to different contexts. Muslims were pushed into an unfair position while they were right in many issues. It would not be just to look for the main reason of this situation just in European Muslims.

Since Europeans recognize Islam as they know only from textbooks and priests, today they become acquainted with Islam by means of immigrants. Are there any real differences between the Islam they met and real Islam? A special field research should be made for the answer. Yet, it is possible to try to make comments in the light of observations and other research. For example, it has been revealed by field research that a significant majority of the French recall Islam with violence, bigotry, pushing of women to the second plan and fanaticism (Antes, 2005: 213). In fact, Islam is a religion of tolerance identified with peace and development which protects women's rights. Islam, which gives importance to human life and aims humans' living in peace and happiness, is incompatible with violence and terrorism which, with a contrary attitude, recognizes no rules and principles and aims at putting an end to human life and keeping individuals or societies in fear and apprehension (Kubat, 2007: 177).

The foreign press is starting to interpret Islam in a different way within the framework of these headings and trying to further increase Islamic 
opposition. As a consequence of such discourses, the impression is created that Muslims are killers of animals and they slaughter them. The impression has been raised that Muslims are defenders of a religion which oppresses girls and wives and disregards women's rights. Unpleasant behaviors of some Muslims reflected in newspapers and magazines such as beating wives, restricting daughters' freedom, forcing the veil cover up and polluting the environment with wastes of sacrificed animals become their most important evidences. For example, Ayaan Hirsi Ali, who was born into a North African Muslim family and is currently active and effective in politics in the Netherlands, says that Islam applies pressure to her as a woman. On one hand, Ayaan Hirsi Ali has been popular due to her sayings that Islam disregards women's rights. On the other hand, it has hurt Islam too much in public opinion. Furthermore, there is a general perception among the public that she owes her position as a Parliamentarian to these discourses.

Undoubtedly, the oppressive family life and lack of education among Muslims with North African origin has been a factor raising such discussions in the European press and agenda. This situation can be assessed as a protective and defensive psychological response of helpless individuals who migrated from their villages in the face of European culture rather than as a reflection of Islam. Of course it would not be wrong to say that this analysis also applies to Turkish immigrants.

\section{Conclusion and Discussion}

In fact, it is not aimed to reveal how intolerant the European society is in the light of these assessments. East and West are geographically integral parts of each other or as two sides of the globe. Likewise, the Eastern civilization and Western civilization are integral parts of the world civilization. Over the last two centuries, Western civilization has been the pioneer in transport and transshipment of the world civilization. However, the Western civilization had not previously been known to take its place in history scene as a carrier of civilization during any period of the known history. It would be quite difficult to establish such a link with the ancient Greek civilization on which it is trying to build its roots in the sense of being Westerner.

Eastern civilizations have assumed the role of being the carrier of civilization for relatively longer. In this respect, examples and trials of coexistence and multiculturalism can be seen in almost many examples of the ancient Eastern civilizations. While Western civilization is undergoing quite a problematic period in terms of coexistence and multiculturalism, it goes ahead of Eastern civilizations regarding technology and knowledge production. However, it remains almost behind the past in relation to experience in multiculturalism and co-existence. 
Contemporary Western civilization countries should adopt the understanding that the 'Universal Declaration of Human Rights' does not exist merely for the people who live on the western side of the globe. Other people on the East hemisphere of the Earth who are struggling to maintain their lives despite many adversities deserve to pursue a better life at least as much as they deserve.

Western mentality approaches with quite rational justification to concepts such as immigration, immigrants, harmony, and coexistence. Here, rationality makes calculation of profit and loss and is the product of a mind which is in pursuit of benefit. From this point; assimilation, humiliation, regarding as second class citizens and otherisation in the name of maximizing profits do not seem really rational if consequences are considered.

Republican presidential candidate Donald Trump's saying "Let's ban entry and exit of Muslims in the US" has also raised reactions from the American public opinion. Another conversation which is a response to his speech is very important. In this respect, it would be beneficial to remember the following sentence by Pope Francis emphasized by American president Obama (2016) during the Congress speech: 'It is the best way of taking the place of killers and bullies to take their hatred and violence as a model'. Obama continued his speech (2016) by saying: 'When politicians insult Muslims, whether citizens or immigrants; When mosques are looted, when children are exposed to discrimination, we will not be more confident; this business is not as they say, this attitude is completely wrong. Being like this moves us to a humiliating position in the eyes of the world. These cases make it even more difficult to reach our goals. Behaving in this way is treason to who we are as a country'.

Obama's emphasis above should go beyond a mere wish. The same emphasis and rationality can be expected from presidents of the European civilization, too. It would be promising for both sides of the globe to enter into such an expectation. Rationality should not be perceived as just caring about yourself. Only if it is perceived as 'mutual coverage of interests', it could return to humanity as a gain in this process.

\section{References:}

Altınay, R. (2004). Müslüman Azınlıklar Tarihine Giriş, Dinî Araştırmalar, 7(19), 335-350.

Antes, P. (2005). Avrupa'da İslam, (Çev: Süleyman Turan), Konya, Marife, 5(2), 203-218.

Arsava, A. (1993). Azınlık Kavramı ve Azınlık Haklarının Uluslararası Belgeler ve Özellikle Kişisel ve Siyasi Haklar Sözleşmesi'nin 27.Maddesi Işı̆̆ında İncelenmesi, Ankara:Ankara Üniversitesi Siyasal Bilimler Fakültesi. 
Arsava, A. (2010). Avrupa Birliği Birincil Azınlıkların Korunmasının Hukuki Dayanağı, Uluslararası Hukuk ve Politika, 23, 1-14.

Aydın, M. \& Yardım, M. (2008), Belçika'da İslamofobi ve Müslümanlara Yönelik Ayrımcılık, Cumhuriyet Üniversitesi Ilahiyat Fakültesi Dergisi, 12(1), 7-32.

Baumann, G. (2006). Çokkültürlülük Bilmecesi Ulusal Etnik ve Dinsel Kimlikleri Yeniden Düşünmek, (Çev: İ.Demirakın), İstanbul: İletişim.

Council of Europe (2011). Birlikte Yaşama, 21.yüzyıl Avrupasında Özgürlüklerin Bir Araya Getirilmesi-Living Together Combining Diversity and Freedom an 21th Century Europe, The Report of the Group of Eminent Persons of Council of Europe, Strasbourg.

Çötok, N. \& Taşdelen, M. (2013). Avrupa Ekseninde Yanabmcı Korkusu ve İslamofobi Algısının Değerlendirilmesi, Turkish Studies, 8(6),1-13.

Deniz, Ş. (2012). Ortadoğu'nun yeniden inşaasının yapı bozumu: Büyük Ortadoğu Projesi üzerine bir analiz. Uluslararası Sosyal Araştırmalar Dergisi, 5 (20), 168 - 183.

Entzinger, H. (2006). The Paralel Decline of Multiculturalism and The Walfare State in The Nederlands, In: Keith Banting And Will Kymlicka (eds.). Multiculturalism and The Welfare State: Recognition and Redistribution in Contemporary Democracies. New-York: Oxford University Press.

EUMC (2006). Muslims in the European Union, Discrimination and Islamophobia, Austria: Manz.

Hidır, Ö. (2007). Tarihte Bir Anti-İslamist Olarak Martin Luther, In: Kadir Canatan and Özcan Hidır (edt.). Batı Dünyasında Íslamofobi ve AntiIslamizm (pp.145-178), Ankara: Eski Yeni Yayınları.

Hussain, A. \& Miller, W. (2006). Multicultural Nationalism (Islamaphobia, Anglophobia and Devolution). New York: Oxford University Press.

Kajanlığlu, B. \& Taş, O. (2009). Türk Basınında AB-Türkiye İlişkilerinin Sunumu: 17 Aralık 2004 Brüksel Zirvesi, Kültür ve İletişim, 12(1), 39-64.

Kalın, İ. (2006). Göç, Entegrasyon Ve Avrupa'nın Tarihsel Biricikliği, Retrieved

From:

http://www.setav.org/index.php?option=com_content\&task=view\&id=128\&1 temid=29 (March 16, 2009).

Kilıç, R. (2006). Islam ve Avrupa Entegrasyonu. Liberal Düşünce, 44, 2738.

Kubat, M. (2007). İslam'ın Barışçı Niteliği ve Batının Onu Şiddet ve Terörle Özdeşleştirme Algısı Üzerine, Akademik Araştırmalar Dergisi, 9(34), 176213.

Kuyucuoğlu, İ. (2013). Danimarka'da Müslüman Toplumun Entegrasyon Sürecinde Dinin İşlevi, Turkish Studies, 8(3), 383-398. 
Mochizuki, K. (2005). Muslim In Europe Why Is It So Difficult, Retrieved From: (March 25, 2008).

www.fcenter.keio.ac.jp/masakoy/awc/2005awc_mochizuki.pdf,

Obama, Barrack H. (2016). State Of Union. Retrieved From: https://www.whitehouse.gov/the-press-office/2016/01/12/remarks-presidentbarack-obama-\%E2\%80\%93-prepared-delivery-state-union-address.

(January 14, 2016).

Özgür, E. (2012). Genişleyen Avrupa Birliği’nin Göçmen İkilemi ve Yaşlanan İşgücü, Öneri, 10(38), 73-85.

Öztürk, E. (2014). İngiltere'de ve Fransa'da İslam'ın Siyallaşması, Research Turkey, Retrieved From: http://researchturkey.org/tr/the-politicisation-ofislam-in-britain-and-france/ (23.11.2015)

Preece, J. (2001). Ulusal Azinlıklar ve Avrupa Ulus Devlet Sistemi, (Çev.Ayşegül Demir), Ankara: Don Kişot.

Roy, O. (2003). Euro-İslam: The Jihad Within?, The National Interest, (71), 63-73.

Rigaux, F. (1997). Mission Impossible: La Définition de la Minorité, Revue Trimestrielle des Droits de l'Homme, 30:155-177.

Şenay, B. (2002). Avrupa Birliği'nin Dini Kimliği ve Avrupa'da Dinler : Hristiyanlı, Yahudilik, Hinduizm, Budizm ve İslam, Uludă̆ Üniversitesi Ilahiyat Fakültesi, 11(1),121-166.

Terzioğlu, S. \& Özarslan, B. (2005). Türkiye'nin Avrupa Birliği'ne Üyelik Sürecinde Azınlıklar Sorunu, Avrasya Dosyası, 11:113-126. 